\title{
'Human Semen Eucharist' Among the Manichaeans? The Testimony of Augustine Reconsidered in Context
}

\author{
Johannes van Oort ${ }^{*}$ \\ University of Pretoria \\ j.van.oort@planet.nl
}

\section{Summary}

Starting from his De haeresibus 46,9-10, the present article examines Augustine's contention that, among the Manichaeans, there was a certain ceremony in which human semen (i.e., sperma and menstrual fluid) was collected and consumed during a eucharistic rite. My contextual analysis of the pivotal passage, haer. 46,9-10, is followed by an overview of scholarly opinions on this text. From here I proceed to interpret the incriminated rite in light of the Seduction of the Archons myth and conclude that, according to Augustine, the Manichaeans consider the 'vital substance' (or 'light' or 'living soul') in the life of plants, animals and human beings, to be the very nature of God, which should be released whenever possible. I finish my research by interpreting the Manichaean practice within a wider 'gnostic' context, in particular Epiphanius' report on the 'Borborites'. My final conclusion is that we should try to understand both Manichaeans (like the 'Catharists') and Gnostics (like the 'Borborites') according to their own logic: both appear to have considered the life-substance of man, i.e., the semen, as divine, and indeed a part of God.

\section{Keywords}

Augustine - Manichaeism - semen eucharist - Catharists - Gnosticism - Epiphanius Borborites - Early Christian heresies - Roman Africa

\section{Introduction}

The chapter on the Manichaeans in Augustine's De haeresibus contains a curious passage (baer. 46,9-10). Until now this section on 'human semen eucharist' (my term) has not been analyzed in context. The present study aims at filling this gap. First I give a new

\footnotetext{
* I would like to acknowledge Jason BeDuhn and Yolande Steenkamp for their attentive reading and assistance. This article was completed with the help of the National Research Foundation (NRF) in South Africa.
} 
translation based upon the most recent text edition. After that follows a brief explanation as well as an overview of opinions on the passage. The next part of my inquiry tries to understand the described 'human semen eucharist' both in the context of Manichaean thinking and Gnostic ideas in general. I finish off with some conclusions.

\section{De haeresibus 46,9-10}

The Latin text in the most recent edition by Roel Vander Plaetse and Clemens Beukers (Corpus Christianorum, Turnhout 1979) runs as follows:

9. Qua occasione, uel potius exsecrabilis superstitionis quadam necessitate, coguntur Electi eorum uelut eucharistiam conspersam cum semine humano sumere ut etiam inde, sicut de aliis cibis quos accipiunt, substantia illa diuina purgetur. Sed hoc se facere negant, et alios nescio quos sub nomine Manichaeorum facere affirmant. Detecti sunt tamen in ecclesia, sicut scis, apud Carthaginem, iam te ibi diacono constituto, quando instante Vrso tribuno, qui tunc domui regiae praefuit, aliqui adducti sunt. Vbi puella illa nomine Margarita istam nefariam turpitudinem prodidit, quae cum esset annorum nondum duodecim, propter hoc scelestum mysterium se dicebat esse uitiatam. Tunc Eusebiam quandam manichaeam quasi sanctimonialem, idipsum propter hoc ipsum passam, uix compulit confiteri, cum primo illa se asseruisset integram, atque ab obstetrice inspici postulasset. Quae inspecta et quid esset inuenta, totum illud turpissimum scelus, ubi ad excipiendum et commiscendum concumbentium semen farina substernitur, quod Margarita indicante absens non audierat similiter indicauit. Et recenti tempore nonnulli eorum reperti et ad ecclesiam ducti, sicut gesta episcopalia quae nobis misisti ostendunt, hoc non sacramentum sed exsecramentum sub diligenti interrogatione confessi sunt.

10. Quorum unus nomine Viator eos qui ista faciunt proprie Catharistas uocari dicens, cum alias eiusdem manichaeae sectae partes in Mattarios et specialiter Manichaeos distribui perhiberet, omnes tamen has tres formas ab uno auctore propagatas, et omnes generaliter Manichaeos esse negare non potuit. Et certe illi libri manichaeis sunt omnibus sine dubitatione communes, in quibus libris illa portenta ad illiciendos et per concupiscentiam dissoluendos utriusque sexus principes tenebrarum ut liberata fugiat ab eis quae captiua tenebatur in eis diuina substantia, de masculorum in feminas et feminarum in masculos transfiguratione conscripta sunt; unde ista, quam quilibet eorum negant ad se pertinere, turpitudo defluxit. Diuinas enim uirtutes quantum possunt imitari se putant ut purgent Dei sui partem; quam profecto, sicut in omnibus corporibus caelestibus et terrestribus atque in omnium rerum seminibus, ita et in hominis semine teneri existimant inquinatam. Ac per hoc sequitur eos, ut sic eam etiam de semine humano, quemadmodum de aliis seminibus quae in alimentis sumunt, debeant manducando purgare. Vnde etiam Catharistae appellantur, quasi purgatores, qui tanta eam purgantes diligentia ut se nec ab hac tam horrenda cibi turpitudine abstineant. ${ }^{1}$

${ }^{1}$ CCL 46, 314-315. 
My fairly litteral translation ${ }^{2}$ runs as follows:

9. For this reason [sc. based upon the so-called 'Seduction of the Archons' myth discussed in $\ 8$ ], or rather because of some demand of their sacrilegious superstition, their Elect are forced to consume a sort of eucharist sprinkled with human seed in order that the divine substance may be freed even from that, just as it is from other foods which they receive. However, they deny that they do this, and assert as true that some others do it, using the name of the Manichaeans. But they were exposed in the Church at Carthage, as you know, for you (i.e., Quodvultdeus) were already a deacon there at the time when, under the prosecution of Ursus the tribune, who was then prefect of the palace, some were brought to trial. At this time a girl by the name of Margarita betrayed this monstrous ugliness (istam nefariam turpitudinem) and claimed, though she was not yet twelve years old, that she had been violated ${ }^{3}$ on account of this wicked rite (propter hoc scelestum mysterium). Then, with difficulty, he compelled Eusebia, some kind of Manichaean nun (quandam manichaeam quasi sanctimonialem), to confess that she had undergone the same treatment because of this very same rite, though, at first, she maintained that she was intact (i.e., virginal) and insisted on being examined by a midwife. When she was examined and when her true condition was discovered, she likewise gave information on that whole extremely ugly crime (totum illud turpissimum scelus) at which flour is sprinkled beneath a couple in sexual intercourse to receive and commingle with their seed. This she had not heard when Margarita gave her testimony, for she had not been present. Even in recent times several of them have been discovered and brought before ecclesiastical authority (ad ecclesiam ducti), as the Episcopal Acts (gesta episcopalia) which you have sent us show. Under careful examination, they confessed that this is no sacrament (sacramentum), but a sacrilege (exsecramentum). 10. One of them, whose name is Viator, claimed that those who commit such acts are properly called Catharists (Catharistas). Nevertheless, though he asserted that there are other groups of the Manichaean sect divided into Mattarians and Manichaeans in the narrower sense, he could not deny that all of these three forms were propagated by the same founder and that all of them are, generally speaking, Manichaeans. And certainly those books of $\mathrm{Mani}^{4}$ (illi libri Manichaer) are unquestionably common to all [sc. Manichaeans], and in these books (in quibus libris) are described these monstrous things relating to the transformation of males into females, and of females into males to attract and to loosen through concupiscence the princes of darkness of both sexes so that the divine substance which held captive $e^{5}$ in them may be set free and escape. This is the source of that ugliness (turpitudo) which anyone of them refuses to admit pertains to them. For they imagine that they are imitating divine powers as far as they can in order that they purge (purgent) a part of their God, which they really believe is held befouled just as much in human seed as it is in all celestial and terrestrial bodies, and in the seeds of all things. And thus it follows that they are just as much obliged (debeant) to purge (purgare) from human seed by eating, as they are in reference to other seed which they consume in their food. This is the reason they are also called Catharists (Catharistae), as it were

\footnotetext{
${ }^{2}$ Where possible, I follow L.G. Müller, The De haeresibus of saint Augustine. A translation with an introduction and commentary, Washington 1956, 89-91, but with significant differences. Consulted as well is R.J. Teske in Arianism and Other Heresies (The Works of Saint Augustine: A Translation for the $21^{\text {st }}$ Century, vol. 18), New York 1995, 43-44.

3 I read, with ms F, Erasmus and the Louvainists, 'uiolatam'.

${ }^{4}$ I read, with i.a. Erasmus and the Louvainists, 'Manichaei'.

${ }^{5}$ It seems reasonable to read with i.a. Erasmus and the Louvainists: 'captiuata'. Cf. e.g. nat. b. 47 and ciu. 11,22 , both with reference to the Manichaean doctrine of the light particles held captive (captivata) in matter.
} 
'purifiers' (purgatores), for they are so attentive to purifying (purgantes) this (part of their God) that they do not refrain even from the horrifying ugliness (turpitudine) of such food.

\section{Brief explanation in context}

In order to understand this passage, we first look at its wider context. The section constitutes an essential part of the long chapter 46 on the Manichaeans, which is close to 1660 words and comprises nearly a sixth of Augustine's whole book De haeresibus and a quarter of his description of eigthy-eight heresies proper. The section appears to have its 'Sitz im Leben' in the inception of the whole book. From the correspondance between Quodvultdeus and Augustine, ${ }^{6}$ we learn that he wrote his work in reply to the requests of the Carthaginian deacon. Quodvultdeus wanted a manual of heresies treating in simple fashion all of the errors arisen since the time of Christ. ${ }^{7}$ This correspondance further reveals that, in the inception of the whole book, Manichaeism is the only heresy mentioned by name. In his first letter to Quodvultdeus, Augustine asks for information about a certain Theodosius. This Theodosius (unknown from other sources ${ }^{8}$ ) is referred to as the person who has exposed some Carthaginian Manichaeans. Augustine wishes to learn how Theodosius and the other former Manichaeans behave themselves in the Catholic faith. ${ }^{9}$ Theodosius as well as the other Manichaeans seem to be the persons hinted at in the Episcopal Acts (gesta episcopalia) of the church of Carthage, which Quodvultdeus had sent to Augustine not long before the composition of baer. ${ }^{10}$ and to which we shall return shortly.

Central to the passage is the story that, on the initiative of the (Catholic) tribune Ursus, ${ }^{11}$ a number of Manichaeans have been arrested and brought before the ecclesiastical authorities. ${ }^{12}$ Possidius, in his vita Augustini, says that all of them were Elect. ${ }^{13}$ During their interrogation by the ecclesiastical authorities-Augustine was

${ }^{6}$ Ep. 221-224 in CSEL 57, 442-454 (Quodvultdeus' two letters and Augustine's provisional answers to his request; cf. CCL 46, 273-281 and, for Quodvultdeus' letters only, R. Braun's 1976-edition in CCL 60,489-492). On the (arch-?) deacon, who in all probability may be identified with the future Carthaginian bishop of the same name, see PAC, 947-949 (Quodvultdeus 5).

${ }^{7}$ Cf. Ep. 221, 3: the work should be 'breuiter, perstricte atque summatim'. Obviously, this was in view of its practical use by_in particular_African clergymen like Quodvuldeus; cf. e.g. ep. 221, 2.

${ }^{8}$ Cf. $P A C, 1109$ s.v. Theodosivs.

${ }^{9}$ Ep. 222, 3: 'Peto etiam mihi rescribere non graueris, quem ad modum sit in fide catholica ille Theodosius, per quem Manichaei nonnulli sunt proditi, et ipsi, quos ab eo proditos putamus esse correctos'.

${ }^{10}$ See above, haer. 46, 10: 'Et recenti tempore nonnulli eorum reperti et ad ecclesiam ducti, sicut gesta episcopalia quae nobis misisti ostendunt'.

${ }^{11}$ Cf. $P A C, 1236$ s.v. Vrsvs.

12 Cf. Possidius, vita, 16.

13 Possidius, ibidem: '... ad quosdam Manichaeorum, quos electos vel electas dicunt ...'; '... feminarum illarum velut electarum ...'. 
among them ${ }^{14}$ — a girl named Margarita gave evidence of their obscene practices and claimed that she had been violated (uiolatam) in the performance of some wicked rite. Augustine relates that the rite consisted of some sort of human semen eucharist, i.e. Elect consuming 'a sort of eucharist sprinkled with human seed so that the divine substance may be freed'. In order to prepare this eucharistia, there was a sexual act between men and women while some flour was spread 'beneath a couple in sexual intercourse to receive and commingle with their seed'. A certain woman Eusebia was forced to admit the same act. To Augustine, all this in actual fact comes as no surprise, because-as he states in $\ 10$ - the books of Mani ${ }^{15}$ describe 'these monstruous things relating to the transformation of males into females, and of females into males to attract and to loosen through concupiscence the princes of darkness of both sexes so that the divine substance which is imprisoned in them may be set free and escape'. In other words, their 'monstrous ugliness' is inspired by the well-known mythical scene of the 'Seduction of the Archons' hinted at in $\int 8$. We shall return to this as well.

First, however, it should be stressed that Augustine's opinion is based upon two instances. ${ }^{16}$ The first is the prosecution of Ursus. This prosecution, with ensuing inquisition, took place around the year $421 .{ }^{17}$ On close reading, however, our passage

${ }^{14}$ Ibid:: 'Inter quos [sc. episcopos] etiam sanctae memoriae Augustinus fuit ...'.

${ }^{15}$ Curiously, Müller (who follows the Benedictine text, Paris 1688, repr. by Migne, PL 42, 21-50) translates 'the Manichaean books', but already the Benedictines clearly read 'Manichaei', which without a doubt means 'of Mani(chaeus)'. For some reason or another, it appears to be difficult to accept that often in A.'s writings the books of Mani bimself are at stake. For the wrong (both ancient and modern) translations of 'libri Manichaei', 'dicta Manichaei', 'Manichaei litteras' etc. in the conf. as 'the books etc. of the Manichaeans', see J. van Oort, "Young Augustine's Knowledge of Manichaeism. An Analysis of the Confessiones and Some Other Relevant Texts', Vigiliae Christianae 62 (2008) 441-466. Roland Teske (who follows CCL 46) also translates 'those books (sc. of the Manichaeans)'. Already the CEuvres complettes de saint Augustin, traduites en Français et annotées par Péronne, Écalle, Vincent (et) Charpentier, vol. 25, Paris 1870, 229, though based on the text of the Benedictines, translate illi libri Manichaei as 'les livres de ces derniers (sc. des Manichéens)'.

16 This fact is neither clear from the translation of Teske who renders (43, my italics): 'And in recent times some of those who were discovered and brought to the church ... confessed', nor evident from the commentary (168) of Müller who indiscriminately translates 'aliqui', 'nonnulli eorum' and 'quilibet eorum' with 'some of them'. The same conflation of instances goes for the relevant entries in $P A C$ (Vrsvs 3, Evsebia, Margarita 2 and Viator), whereas s.v. 'Qvodvvltdevs 5' it explicitly runs: 'C'est encore vers 421 - et le tribun Vrsus manifestant à Carthage son action dans le domaine religieux cette fois-ci à l'encontre des manichéens_ - qu'un diacre carthaginois du nom de Quoduultdeus est mis au courant de l'existence dans cette église d'un group d'Elus et d'Elues. A propos du procès intenté devant l'autorité ecclésiastique, le même diacre adresse plus tard (avant 427/430) à Augustin les Actes épiscopaux concernant cette affaire' (947, my italics). All this, however, does not take into account A.'s explicit speaking of 'in recent times', which in my opinion refers to another instance.

${ }^{17}$ Cf. PAC 1236 s.v. Vrsvs, with reference to Quodvultdeus, De promissionibus et praedicationibus Dei III, 38 (44). 
reveals there also was another one: 'Even 18 in recent times several of them (nonnulli) have been exposed and brought before ecclesiastical authority, as the Episcopal Acts which you have sent us show'. 'Nonnulli' refers to Manichaeans in general, and not to the 'aliqui' of Ursus' prosecution which has been spoken of in the preceding sentences. ${ }^{19}$ The text continues by telling that among these 'nonnulli' of the Episcopal Acts was a certain Viator, who claimed that 'those who commit such acts are properly called Catharists' and also spoke of 'Mattarians'20 and 'Manichaeans in the narrower sense'. After telling that Victor 'could not deny that all of these three forms (tres formas) were propagated by the same founder and that all of them are, generally speaking, 'Manichaeans', Augustine continues with further remarks on the contents of Mani's books, namely that 'the source of that ugliness which anyone of them refuses to admit pertains to them'. Based on Augustine's speaking of 'recenti tempore', there is reason to suppose that this event and the ensuing Episcopal Acts are to be dated shortly before he wrote his haer., i.e. shortly before about 428-429.21 If indeed the former Manichaean Theodosius mentioned in ep. 222 was involved in the event, one may on the basis of the usually accepted date of epp. 221-224, sc. 427,22 even suppose that it happened shortly before that year. In any case, there appears to be report of two different events, one c. 421, the other c. 427.

\section{Divergent opinions}

More important, of course, is the question of what to think of the rite described in the passage. In the context of his heresiological report on the Manichaeans, Augustine's two paragraphs haer. 46, 9-1023 focus on their 'sacrilegious superstition', which he also indicates as an 'ugliness', a 'monstrous ugliness', an 'extremely ugly crime' and, finally, as a 'horrifying ugliness'. Three times he uses the noun 'turpitudo' and once the related adjective 'turpis' in his description, while at the same time the derogative adjective 'exsecrabilis' of his opening sentence resounds in the verdict at the end of $₫ 9$ : 'hoc non sacramentum sed exsecramentum ...'. From Augustine's rhetorical skills one thing immediately becomes clear: the issue at stake is considered to be of an utmost objectionable character, an exsecrabilis superstitio indeed.

\footnotetext{
${ }^{18}$ Or: 'And also ...'. For the translation of 'et', see e.g. A. Blaise, Dictionnaire latin-français des auteurs chrétiens. Revu spécialement pour le vocabulaire théologique par H. Chirat, Turnhout 1954, 316 s.v. et, 2: 'et aussi, aussi, même (CIC)'.

${ }^{19}$ Haer. 46, 9: '... aliqui adducti sunt' etc.

20 Already well known to Augustine; cf. c. Faust. 5, 5.

21 This date for haer. also accepted by M. Scopello, 'Haeresibus ad Quoduultdem (De -)', AL 2 (20042010), 281.

22 E.g. J. Divjak, 'Epistolae', AL 2 (2004-2010), 997-998 and 1033-1034.

23 The (not so fortunately made) division into paragraphs is due to later editors.
} 
But should we take Augustine's description as being consonant with reality? Since many years scholarly opinion on the subject has been widely divergent. In the over 1.500 pages of his Histoire (Critique) de Manichée et du Manicheisme, ${ }^{24}$ the founding father of Manichaeology, Isaac de Beausobre, payed scant attention to the passage, ${ }^{25}$ while rejecting its contents on subjective grounds. ${ }^{26}$ Ferdinand Christian Baur, however, in his also ground braking Das manichäische Religionssystem nach den Quellen neu untersucht und entwickelt, ${ }^{27}$ while stressing the fact that Augustine's description is 'an incrimination', ${ }^{28}$ at the same time stated that 'it is credible that gnostic and Manichaean doctrines not infrequently resulted in such shameful errors'. ${ }^{29}$ Yet Baur did not elaborate on the topic in any further detail. ${ }^{30}$ Otherwise was the opinion of Prosper Alfaric in his well-known study on Augustine's intellectual career. ${ }^{31}$ Alfaric not only discussed the passage haer. 46, 9-10 in considerable detail, but also referred to parallels in the works of Leo the Great, Cyril of Jersualem and some of Augustine's own writings. ${ }^{32}$ As for the historical reliability of the described issue, his conclusion was in the negative: 'Leur Eucharistie

24 The two volumes first appeared in Amsterdam 1734-1738 and have been reprinted several times in the $20^{\text {th }} \mathrm{c}$.

25 I. de Beausobre, Histoire Critique de Manichée et du Manichéisme, II, Amsterdam 1739, 387-389.

26 See, in particular, his concluding remarks (Histoire, II, 389): 'Je rejette donc absolument le récit de S. Augustin. Je ne l'accuse pas de mensonge, mais je suis persuadé qu'il a été trompé par une Traduction, ou plutôt, par quelque Extrait infidèle du Thrésor de Manichée'. I see two main reasons for this curious opinion. First, because De Beausobre's description of Mani and the Manichaeans is remarkably positive (like their successors, the Waldensians, they are precursors of the Protestants!) and the account of haer. 46, 9-10 does not fit this picture. Secondly, because De Beausobre underrates A. as a reliable source and prefers Eastern sources. Yet it should be noted that a similar passage in Greek from Cyril of Jerusalem's Catechesis VI (on which see my forthcoming VC-article 'Another Case of Human Semen Eucharist Among the Manichaeans? Notes on the "Ceremony of the Fig" in Cyril of Jerusalem's Catechesis VI') only scantly figures in his account.

27 Tübingen 1831 (repr. Göttingen 1928; Hildesheim-New York 1973).

28 Baur, Das manichäische Religionssystem, 280: 'Beschuldigung'.

${ }^{29}$ Baur, ibidem: 'Es ist allerdings sehr glaublich, daß gnostische und Manichäische Lehren schändliche Verirrungen dieser Art nicht selten zur Folge gehabt haben', with reference to Epiphanius, Haer. XXVI,4.5.9.11.

30 On p. 289 he again characterizes A.'s description as a 'Mißdeutung' and further states that, in actual fact, the name Catharistae for the Manichaeans is correct: 'Der Name ist für die allgemeine Bestimmung, die die Electi hatten, so passend, daß er wohl eine ebenso allgemeine Bedeutung hatte, als der ihm entsprechende und mit ihm zusammenhängende Name Katharer, welchen die Manichäer des Mittelalters führten. Die Reinigenden mußten doch selbst auch die Reinen seyn'. ---I may remark here in passing that (in line with Baur) I consider a reference to a testimony such as enclosed in haer. 46, 10 more convincing as the real source of the (attributed!) name 'Cathars' for the well-known mediaeval dualistic movement than the (in modern research) usual reference to the followers of Novatianus (c. 250). For 'Katharoi' in Manichaean sources, see e.g. Kephalaia (ed. Polotsky) 44,27. Cf. e.g. CMC 98.

31 Prosper Alfaric, L'évolution intellectuelle de saint Augustin, I: Du manichéisme au néoplatonisme, Paris 1918.

32 I.e. Leo’s s. 16, 4; Cyril's Cat. VI, 23 fin.33 init.; Augustine's mor. 66 and nat. b. 47. 
aspergée de semence humaine semble aussi légendaire que le meurtre rituel si souvent imputé aux Chrétiens pendant les premiers siècles'. ${ }^{33}$

One gets the impression that, since Alfaric, most researchers have subscribed to this opinion and hence consider the subject to be legendary. In several books on Manichaeism, and also in general overviews of the religious movement, the issue is not mentioned at all. ${ }^{34}$ This also goes for the leading collection of texts in translation by Alexander Böhlig (in collaboration with Jes Peter Asmussen): Augustine's haer. 46 is presented in full, apart from the $\iint 9-10.35$ At first glance the still highly acclaimed monograph of Henri-Charles Puech ${ }^{36}$ seems to be somewhat different, but Puech rejects the historical reliablity of Augustine's account as well. ${ }^{37}$

Although modern research shows some exceptions to this rule, as yet no author has provided an indepth study of the (possible) reasons to accept Augustine's account. Anthony Moon, in the commentary to his translation of Augustine's De natura boni, believes Augustine to be reliable, but he does not go into the subject in sufficient detail. 38 The same goes for Liguori Müller in the commentary to his translation of De haeresibus. 39 A rather elaborated overview of the passage has been provided by François Decret in his extensive publication on Manichaean Africa in the fourth and fifth centuries, ${ }^{40}$ but he mainly confines himself to exposing Augustine's text. The same goes for some passages

33 Alfaric, L'évolution, 165 n. 1.

${ }^{34}$ E.g. G. Widengren, Mani und der Manichäismus, Stuttgart 1961 (= Mani and Manichaeism, London-New York 1965); M. Tardieu, Le manichéisme, Paris 1981 (1997²) (= Manichaeism, Urbana \& Chicago 2009); S.N.C. Lieu, Manichaeism in the Later Roman Empire and Medieval China, Tübingen 1992; A. Böhlig, 'Manichäismus', TRE 22 (1992) 25-45; W. Sundermann, 'Manicheism, i: General Survey', Encyclopedia Iranica (online, retrieved 10 Nov. 2014. According to the opening sentence, 'this article is designed to provide a general survey of Manichean doctrine and religious practice).

35 A. Böhlig (unter Mitwirkung von J.P. Asmussen), Die Gnosis, Dritter Band, Der Manichäismus, ZürichMünchen 1980, 138-143. The deliberate omission is indicated by “...” on p. 140.

${ }^{36}$ H.-C. Puech, Le manichéisme, Paris 1949.

${ }^{37}$ Puech, Manichéisme, 182 n. 365: 'Quant aux accusations portées contre les Manichéens par leur ennemis de cummunier sous des espèces obscènes (Cyrille de Jerusalem, Cat. VI, 23 et 33; Augustin, De haer., 46 et l'allusion dans C. Fortunatum, 3)—calomnies dont l'origine et la teneur peuvent du reste s'expliquer aisément-, elles ne sauraient, de toute évidence, être prises au pied de la lettre'. Cf. Puech, 'Liturgie et pratiques rituelles dans la manichéisme', Annuaire du Collège de France 55 (1954-1955) 177-183 (now in Puech, Sur le manichéisme et autres essais, Paris 1979, *-*).

38 A.A. Moon, The De natura boni of Saint Augustine. A Translation with an Introduction and Commentary, Washington 1955, 253-254, esp. the remark with regard to haer. 46,9-10 (254): 'What does seem possible [my italic] is the scandal given by the dissidents'. See also Moon, De natura boni, 239-240 on nat. b. 45. ${ }^{39}$ See above, n. 2.

${ }^{40} \mathrm{~F}$. Decret, L'Afrique manichéenne (IV ${ }^{e}-V^{e}$ siècles). Étude historique et doctrinale, I-II, Paris 1978, I: 221-226 and II: $171-178$. 
in the highly acclaimed Prosopographie de l'Afrique Chrétienne composed by André Mandouze and his collaborators. ${ }^{41}$ When relevant, we will come back to them.

\section{Trying to understand Augustine's charge}

From Augustine's account one thing is clear: he refers to two different occasions and for both of them his addressee Quodvultdeus is the pre-eminent witness. First, there is the testimony of the Manichaeans' deposition 'in the Church at Carthage' from about 421, when Quodvultdeus 'was already a deacon there'. All other readers of the book addressed to him (first of all the contemporary readers, in Carthage and elsewhere) could check Augustine's allegations. Secondly, there are, from more recent times, the Episcopal Acts which Quodvultdeus just sent to Augustine and which testify to the same ritual of 'human semen eucharist'. It is difficult to see that, in the case of such a severe charge, and with reference to such different sources, Augustine would have concocted the whole matter.

One may opine that Augustine invented the charge of the year 421 and that, subsequently, the second case of 427 was conceived on the basis of his authority. A strong argument could be that he was in search of such a charge since his earliest antiManichaean writings. Already in mor. 2, 66 (written c. 388/9) he had hinted at such a rite. ${ }^{42}$ In c. Fort. 3 (August 392) he had stated that only the Elect fully know the Manichaean morals and, at the same time, with reference to a Manichaean eucharist, that hidden things happened among the Elect. ${ }^{43}$ In nat. b. 47 (written, in all probability, c. 404/5), in the context of a long quote from the $7^{\text {th }}$ book of Mani's Thesaurus on the myth of the Seduction of the Archons, ${ }^{44}$ a myth which he further illustrated by a lengthy quote

41 Prosopographie Chrétienne du Bas-Empire, I: André Mandouze, Prosopographie de l'Afrique Chrétienne (303533), Paris 1982.

42 Mor. 2, 66: 'Cur enim de tritico et de faba et de lenticula aliisque seminibus, cum his uescimini, liberare uos uelle animam creditur, de animalium seminibus non credatur? (...) Et quia non possunt ab auditoribus uestris purganda uobis talia semina afferri, quis non suspicetur secretam de uobis ipsis inter uos fieri talem purgationem et ideo illis, ne uos deserant, occultari? Quae si non facitis, quod utinam ita sit, uidetis tamen quantae suspicioni uestra superstitio pateat'. In the NPNF-translation: 'For why should it be true regarding corn and beans and lentils and other seeds, that when you eat them you wish to set free the soul, and not true of the seeds of animals? (...) And as your followers [sc. auditores) cannot bring these seeds to you for purification, who will not suspect that you make this purification secretly among yourselves, and hide it from your followers, in case they should leave you?'

${ }^{43}$ C. Fort. 3: 'de moribus autem uestris plene scire possunt, qui electi uestri sunt. (...) quid autem inter uos agatis, qui electi estis, ego scire non possum, nam et eucharistiam audiui a uobis saepe quod accipiatis; tempus autem accipiendi cum me lateret, quid accipiatis unde nosse potui'. In the NPNFtranslation: 'but concerning your morals only those who are your Elect can fully know. (...) But what you who are Elect do among yourselves, I have no means of knowing. For I have often heard from you that you receive the Eucharist. But since the time of receiving it was concealed from me, how could I know what you receive?'

${ }^{44}$ Nat. b. 44. 
from Mani's Epistula fundamenti, ${ }^{45}$ he had emphatically declared that the Manichaeans acted according to this myth and hence committed 'sacrilegious and incredible turpitudes'. ${ }^{46}$ Apart from several explicit remarks on the inevitable consequences of the said myth, ${ }^{47}$ in nat. $b$. he had also reported stories he heard in Rome about Manichaeans who committed such 'turpitudes' in Paphlagonia and Gaul. ${ }^{48}$ Now, near the end of his life, Augustine had found definitive proof in Africa's capital Carthage.

At first sight much seems to speak for such a reasoning and one may be inclined to side with Alfaric and others. However, after close reading of the relevant texts in context, while at the same time considering the factual circumstances, another conclusion appears to be inevitable. First there is the historical context as discussed above: Quodvultdeus as a witness both in the first and the second case. Besides, there are the many other contemporaries, for instance those involved in the first case under Ursus and those involved in the second one resulting in the Episcopal Acts. Apart from all these persons, there are the contemporary readers of haer., first of all in Carthage. If things would not have happened this way (or would not have happened at all), would not they have protested against such a misrepresentation? Moreover, there is the person of Theodosius, who had exposed some Carthaginian Manichaeans: ${ }^{49}$ one can not imagine that we are dealing with an invented person, dreamt up already some time before haer. 46 was written down.

Indeed, it is fully correct to stress Augustine's instrumental role in the whole issue. After many years of suspicion, he could finally prove his conjectures to be true. Possidius even emphasizes that it was Augustine who disclosed 'their damnable blasphemies from places in their books which they accept as being from Mani'. ${ }^{50}$ This happened during their examination by Catholic bishops in a church at Carthage, ${ }^{51}$ after they had been

45 Nat. b. 46.

46 Nat. b. 44: 'sacrilegas et incredibiles turpitudines'.

${ }^{47}$ E.g. nat. b. 45: 'quis non digne credat eos facere, quod inter virtutes coelorum et principes tenebrarum fieri in Thesauro suo legunt; quandoquidem et carnes suas de gente tenebrarum esse dicunt, et in eis ligatam teneri vitalem illam substantiam, partem Dei, credere atque affirmare non dubitant?' In the NPNF-translation: 'who may not properly believe, that they do what they read in the Thesaurus was done among the powers of heaven and the princes of darkness; since indeed they say that their flesh is also from the race of darkness, and since they do not hesitate to believe and to affirm that the vital substance fettered in them is a part of God?'

48 Nat. b. 47. Decret, L'Afrique manichéenne, I, 133-134, seems to be right in his opinion that 'in Gallia' will refer to the case of Priscillien and his followers who, 'à tort ou à raison' (133), were denounced as 'Manichaeans'.

49 Ep. 222, 3 (see discussion above, and n. 7 and 9).

${ }^{50}$ I.e. written by Mani. This is another case (see n. 15, above) where 'Manichaei' should be read litterally as 'of Mani(chaeus)'. Cf. full Latin text below.

51 'In ecclesia' in haer. 46, 9 ('Detecti sunt tamen in ecclesia' etc.) does not mean that they were found, as some hidden Manichaean cell, within the Catholic Church (cf. the Manichaean auditor Victorinus, who was a sub-deacon in the Catholic Church of Malliana as discussed in A.'s ep. 236; cf. the cryptoManichaeans in Rome during the pontificate of Leo I). Possidius, vita, 16 clearly refers to the preceding 
detected by procurator Ursus. They were examined there, in a hearing with formal record (ad tabulas). ${ }^{52}$ Augustine was the person 'who knew the accursed sect better than the others did'; he read from the Manichaean books (one may suppose, from Mani's Thesaurus and from Mani's Fundamental Letter, both writings being thorougly known to him $^{53}$ ) and even 'brought them to a confession of those damnable blasphemies'. ${ }^{54}$ One may understand Müller in his opinion that 'there is no reason for rejecting' Augustine's testimony. 55

\section{Augustine's charge and Manichaean doctrine}

Neither Müller nor anybody else, however, tried to understand from the point of view of Manichaean doctrine what seems to have really happened. In order to find this out, the best point of departure seems to be what Augustine passes on from Mani's own writings in De natura boni. First he transmits a passage from the seventh book of Mani's

activity of Ursus, and then states: 'atque ad ecclesiam ab eodem (sc. Ursus) deducerentur et perducerentur, ab episcopis ad tabulas auditi sunt'. This, however, is not clear from several modern translations of haer. 46,9 (e.g. G.J. Perl, Aurelius Augustinus, "Nutzen des Glaubens" (De utilitate credendi); "Die zwei Seelen" (De duabus animabus), Paderborn 1966, XXI: 'Dennoch hat man sie, wie du weißt, in einer Kirche bei [sic] Karthago entdeckt'; cf. already Péronne, Écalle, Vincent (et) Charpentier in CEuvres complètes de saint Augustin (n. 15), 228: 'Cependant ils ont été découverts, vous le savez, dans une église de Carthage'. One should, however, distinguish between the original discovery (by Ursus) and the ensuing 'exposition' in the church. The authors of 'Quodvvltdevs 5' in PAC, 947 mistakenly write: 'un diacre carthaginois du nom de Quoduultdeus est mis au courant de l'existence dans cette église d'un groupe d'Elus et d'Elues'.

52 As indicated above, these acts, written down by stenographers, are not the same as the acta episcopalia which, according to haer. 46, 9, Possidius later sent to Augustine. They are taken to be identical, however, by the author(s) of $P A C$ s.v. Quodvvltdevs 5, 947 ("A propos du procès intenté devant l'autorité ecclésiastique, le même diacre [sc. Quodvultdeus] adresse plus tard (avant 427/430) à Augustin les Actes épiscopaux concernant cette affaire') and s.v. Viator, 1149 ('Viator, manichéen du nombre de ceux qui ont été découverts à Carthage et conduits devant l'autorité ecclésiastique, selon les Actes adressés à Augustin par le diacre Quoduuldeus ...'). The Benedictines already made a fine (but often overlooked) distinction in a note in their edition of Possidius' Vita, ch. XVI: 'Ad tabulas, id est, notariis excipientibus et in tabulas inferentibus interrogata et responsa: sicque notariorum opere confecta sunt illa gesta, quae hic ecclesiastica dicuntur, et in libro de Haeresibus, haer. 46, episcopalia' (my italics). See MPL 33, $46 \mathrm{n}$. (a).

${ }^{53}$ See e.g. nat. b. and c. ep. Man. One can only speculate about the provenance of those books of Mani in Carthage. Were they already at the disposal of the local Catholic church? Or brought forward by Augustine? Or confiscated by Ursus and put at the disposal of the assembled bishops? ---It could also be that the plural 'books' (libri) only refers to the Thesaurus, which—see below-both according to Augustine and his pupil Evodius consisted of (at least) seven books.

54 Possidius, vita 16: 'Inter quos [sc. episcopos] etiam sanctae memoriae Augustinus fuit, qui prae caeteris illam exsecrabilem sectam noverat, et eorum prodens ejusmodi damnabilis blasphemias ex locis librorum, quos illi accipiunt Manichaei, usque ad confessionem earundem blasphemiarum eos perduxit.' ${ }_{55}$ Müller, The De haeresibus of saint Augustine, 168. 
Thesaurus. ${ }^{6}$ Here, Mani relates the episode of his myth, which in scholarly literature since François Cumont ${ }^{57}$ is called 'the seduction of the archons'. In Augustine's quote ${ }^{58}$ it runs:

Tunc beatus ille Pater, qui lucidas naues habet diuersoria et habitacula secundum ${ }^{59}$ magnitudines, pro insita sibi clementia fert opem, qua exuitur et liberatur ab inpiis retinaculis et angustiis atque angoribus suae uitalis substantiae. Itaque inuisibili suo nutu illas suas uirtutes, quae in clarissima hac naui habentur, transfigurat easque parere facit aduersis potestatibus, quae in singulis coelorum tractibus ordinatae sunt. Quae quoniam ex utroque sexu masculorum ac feminarum consistunt, ideo praedictas uirtutes partim specie puerorum inuestium parere iubet generi aduerso feminarum, partim uirginum lucidarum forma generi contrario masculorum, sciens eas omnes hostiles potestates propter ingenitam sibi letalem et spurcissimam concupiscentiam facillime capi atque iisdem speciebus pulcherrimis, quae adparent e ${ }^{60}$ mancipari hocque modo dissolui. Sciatis autem hunc eundem nostrum beatum Patrem hoc idem esse, quod etiam suae uirtutes, quas ob necessariam causam transformat in puerorum et uirginum intemeratam similitudinem. Utitur autem his tamquam propriis armis, atque per eas suam conplet uoluntatem. Harum uero uirtutum diuinarum, quae ad instar coniugii contra inferna genera statuuntur quaeque alacritate ac facilitate id, quod cogitauerint, momento eodem efficiunt, plenae sunt lucidae naues. Itaque cum ratio poposcerit, ut masculis adpareant eaedem sanctae uirtutes, illico etiam suam effigiem uirginum pulcherrimarum habitu demonstrant. Rursus, cum ad feminas uentum fuerit, postponentes species uirginum puerorum inuestium speciem ostendunt. Hoc autem uisu decoro illarum ardor et concupiscentia crescit, atque hoc modo uinculum pessimarum cogitationum earum soluitur uiuaque anima, quae eorumdem membris tenebatur, hac occasione laxata euadit et suo purissimo aeri miscetur, ubi penitus ablutae animae ascendunt ad lucidas naues, quae sibi ad uectationem atque ad suae patriae transfretationem sunt praeparatae. Id uero, quod adhuc aduersi generis maculas portat, per aestus atque calores particulatim descendit atque arboribus ceterisque plantationibus ac satis omnibus miscetur et caloribus diuersis inficitur. Et quo pacto ex ista magna et clarissima naui figurae puerorum et uirginum apparent contrariis potestatibus, quae in coelis degunt quaeque igneam habent naturam, atque ex isto aspectu decoro uitae pars, quae in earumdem membris habetur, laxata deducitur per calores in terram: eodem modo etiam illa altissima uirtus, quae in naui uitalium aquarum habitat, in similitudine puerorum ac uirginum sanctarum per suos angelos apparet his potestatibus, quarum natura frigida est atque humida, quaeque in coelis ordinatae sunt. Et quidem his, quae feminae sunt, in ipsis forma puerorum apparet, masculis uero uirginum. Hac uero mutatione et diuersitate diuinarum personarum ac pulcherrimarum humidae frigidaeque stirpis principes masculi siue feminae soluuntur atque id, quod in ipsis est uitale, fugit: quod uero resederit, laxatum deducitur in terram per frigora et cunctis terrae generibus admiscetur.

56 Nat. b. 44.

${ }^{57}$ See esp. the appendix 'La Séduction des Archontes' in F. Cumont, Recherches sut le Manichéisme, Bruxelles 1912, 54-68.

${ }^{58}$ CSEL 25, 881-884. The same passage in (nearly) the same wording is quoted by Evodius in his De fide contra Manichaeos (CSEL 25, 956-957). Evodius, however, apart from a passage from the second book of the Thesaurus (CSEL 25, 952; cf. Augustine, c. Fel. 2,5) also provides a unique section from the first book of the Thesaurus (CSEL 25, 955), which testifies to the fact that Mani's Thesaurus was well diffused in the Latin speaking world. Cf. e.g. Hieronymus, c. Vigil. 6.

${ }^{59}$ Other reading: seu.

${ }^{60}$ Other reading omits 'et'. 


\section{In translation: ${ }^{61}$}

Then that blessed Father, who has bright ships as lodgings and dwelling places, in accordance with their sizes, ${ }^{62}$ by virtue of his innate mercy brings help to draw out and set free his vital substance from the impious bonds and straits and torments in which it is held. And so by his own invisible nod he transforms his powers (virtutes), which are held in this most brilliant ship, ${ }^{63}$ and makes them to show themselves to the hostile powers (potestates) which have been set in the various parts of the heavens. Since these (potestates) consist of both sexes, male and female, he orders the aforesaid powers (virtutes) to bring forth partly in the form of beardless boys to the females of the hostile race, partly in the form of bright virgins to the males of the hostile race. For he knows that all these hostile powers (potestates), on account of the deadly and most foul lust (concupiscentia) innate in them, are very easily taken captive, delivered up to these most beautiful forms which appear, and in this manner they are dissolved (dissolvi). Understand that this same blessed Father of ours is identical with his powers (virtutes), which for a necessary purpose (causa) he transforms into the undefiled likeness of boys and virgins. These he uses as his own instruments (armis), and through them he accomplishes his will.

The bright ships are in fact full of these divine powers (virtutes), which are stationed, like mates (ad instar coniugii), opposite the infernal races, and who with alacrity and ease effect at the very moment what they have planned (cogitaverunt). Therefore, when the plan (ratio) demands that these same holy powers (virtutes) should appear to males, immediately they show themselves by their dress in the form (effigies) of most beautiful virgins. Again, when they represent themselves to females, they put aside their beautiful form (species) of virgins and display the beautiful form (species) of beardless boys. But by this handsome appearance of theirs, ardour (ardor) and lust (concupiscentia) increase, and in this way the chain (vinculum) of their evil thoughts is broken and the living soul (viva anima) which was held bound in their members (membris), relaxed (laxata) by this occasion, escapes, and is mingled with the purest air which is its native element. When the souls are thoroughly cleansed, they ascend to the bright ships, which have been prepared for their ascent and transport to their own fatherland.

But that which still bears the stains of the adverse race, descends step by step by heat and passion (per aestus atque calores), ${ }^{64}$ and gets mixed up with trees and other plants and all seeds, and is dyed diverse colours. The figures (figurae) of boys and virgins from that great and most glorious ship appear to the hostile powers (potestates) whose home is in the heavens and have a fiery nature, and from that handsome appearance (ex isto aspectu decoro) the part of the life which is held in their members (membris) is released (laxata) and brought down to earth by passion (per calores). In the same way that most high power (virtus), which dwells in the ship of vital waters, appears by means of his

${ }^{61}$ The division in sections like in A. Adam, Texte zum Manichäismus, Berlin 1969², 2-4.

62 Perhaps this refers to the usual difference in size between (small) lodgings and (bigger) dwelling places, like the visible difference between the 'bright ships', i.e. moon and sun. If the reading 'seu' is accepted, the word 'magnitudines' refers to both sun and moon as being 'greatnesses'.

${ }^{63}$ Evidently the sun is meant. In several versions of the Manichaean myth the Third Messenger appears in the sun in his brilliant nakedness in a female form as the Virgin of Light before the male archons, and in a male form before the female archons. In Acta Archelai VIII (ed. C. Beeson, GCS 16, 12) the sun is called 'the greater heavenly body' ('... luminare maius, id est sol ...').

${ }^{64}$ Evidently the 'passioned heat' of some 'sexual' excitement is meant. According to Manichaean doctrine, concupiscence (epithymia) is characteristic to all evil matter. 
messengers in the shape of boys and holy virgins to those powers (potestates) whose nature is cold and wet, and which also are set in the heavens. And indeed to those which are female, it appears in the form of boys, but to the males, in the form of virgins. By this change and diversity of divine and most beautiful persons, the princes of the wet and cold race, whether male of female, experience release (solvuntur), and the vital element in them escapes. But once that which remains is released (laxatum), it is brought down to earth by cold and is mingled with all the species (generes) of earth.

This part of Mani's cosmogonic myth is pre-eminently sexual, and this essential feature (and its consequences) particularly aroused Augustine's abhorrence. ${ }^{65}$ God, the blessed Father, who in the battle with the potestates of darkness has lost part of his light elements, transforms his virtutes ${ }^{60}$ into beautiful boys and virgins in order to rescue the light held captive by the evil potestates (elsewhere termed the Archons). God is even identical with his virtutes, 'which for a necessary purpose (causa) he transforms into the undefiled likeness of youths and maidens'. According to Augustine (and mainstream philosophical opinion), however, God is 'undefilably, inviolably, incorruptibly', ${ }^{67}$ a doctrine of God which completely runs counter to Manichaean theology in which God is 'fettered, oppressed, polluted, to be released, liberated and purified, as they say'. ${ }^{8}$ Augustine adds to this description of the Manichaean God that his liberation happens through the course of the sun and the moon (the 'bright ships' ${ }^{6}$ in the quote from Mani's Thesaurus) and through the virtutes of light, but also through their Elect. ${ }^{70}$ In his opinion, 'it is horrible to say how this form of their most unspeakable error induces them, even if it does not bring them, to sacrilegious and incredible shamefulness'. ${ }^{71}$

In De natura boni 44 Augustine still considers a 'human semen eucharist' a mere possibility. He again hints at it as being a possibility in the following chapter: 'For if, as they say, a part of God (pars Dei) is fettered in all seeds, and is purified by the Elect when they eat it, who may not rightly (digne) believe, that they do what they read in the Thesaurus was done among the virtutes of heaven and the principes of darkness, since indeed they say that their own bodies also come from the race of darkness, and since they do not hesitate to believe and to affirm that that vital substance (vitalis illa substantia), a pars

${ }^{65}$ Cf. e.g. c. Faust. 20, 6 and c. Fel. 2, 7.

${ }^{66}$ Elsewhere also called his 'sons' or 'arms'. See for a rather detailed overview of the complicated Manichaean myth (which came down to us in several accounts) my entry 'Manichaeism' in RPP VIII, 25-30.

${ }^{67}$ Nat. b. 44: 'incoinquinabiliter, inuiolabiliter, incorruptibiliter'. Cf. e.g. c. Fort. 1.

${ }^{68} \mathrm{Nat}$. b. 44: 'ligatam, oppressam, pollutam, quam solui, liberari, purgarique dicunt'.

${ }^{69}$ Elsewhere (e.g. in the Coptic Manichaean Psalmbook and Kephalaia, cf. S. Clackson, E. Hunter and S.N.C. Lieu, Dictionary of Manichaean Texts, I, Texts from the Roman Empire, Turnhout 1998, 172) indicated as the 'ships of light'. In the common accounts of the Manichaean myth the (waxing and waning) moon transports the released light particles to the sun and from there they ascend to the kingdom of light.

${ }^{70}$ Nat. b. 44: 'sed ligatam, oppressam, pollutam, quam solui, liberari, purgarique dicunt, non solum per discursum solis et lunae, et uirtutes lucis, uerum etiam per electos suos'.

71 Nat. b. 44: 'hoc genus nefandissimi erroris quam sacrilegas et incredibiles turpitudines eis suadeat, etiamsi non persuadeat, horribile est dicere.'. 
$D e i$, is bound in them?'72 Then, in ch. 46, Augustine relates the Manichaean view that certain principes of the race of darkness created Adam in order that the light might be held by them lest it should escape'73 - a well-known view which he illustrates by a long quote from Mani's Epistula fundamenti.

In the following ch. 47, however, he also contends: 'if a part of their God is fettered by the copulation of males and females, which they profess to release and purge by eating it, the necessity (necessitas) of this unspeakable error compels them not only to release and purge the part of God from bread and vegetables and fruits, which deed they are seen publicly to partake of, but also from that which might be fettered through copulation, if conception should take place'. ${ }^{74}$ And finally, after relating what he had heard about Manichaeans' practice in Paphlagonia and Gaul, ${ }^{75}$ and telling that they committed 'human semen eucharist' on the basis of the myth descibed in Mani's Thesaurus, ${ }^{76}$ he also states that the Manichaeans maintained that only some schismatics of their Elect committed the crime. But, in actual fact, this does not make an essential difference to Augustine: 'even if they do not themselves practise this thing, some who do practise it do it on the basis of their books. Therefore let them reject the books, if they abhor the crime, which they are compelled to commit, if they hold to the books'..$^{77}$

It should be stressed that, in essence, what is written in nat. b. 44-47 coincides with baer. 46. In other words, the reasoning of c. 404/5 matches the story of 421 . This suspect coincidence, however, does not provide definite proof that the story of 421 and, in its wake, the story of c. 426/7, are mere inventions. In our view, the described historical circumstances as well as the (possible) testifications of so many a contemporary are more important and even decisive.

\footnotetext{
72 Nat. b. 45: 'Si enim, sicut dicunt, in omnibus seminibus est ligata pars dei, et ab electis manducando purgatur; quis non digne credat eos facere, quod inter uirtutes coelorum et principes tenebrarum fieri in Thesauro suo legunt; quandoquidem et carnes suas de gente tenebrarum esse dicunt, et in eis ligatam teneri uitalem illam substantiam, partem Dei, credere atque affirmare non dubitant?'

${ }^{73}$ Nat. b. 46: '...ut lumen ab eis ne fugeret teneretur'.

74 Nat. b. 47: 'si per coitum masculorum et feminarum ligatur pars Dei, quam se manducando soluere et purgare profitentur, cogit eos huius tam nefandi erroris necessitas, ut non solum de pane et oleribus et pomis, quae sola uidentur in manifesto accipere, sed inde etiam soluant et purgent partem Dei, unde per concubitum potest, si feminae utero concepta fuerit, colligari'.

75 Cf. n. 48 and related main text above.

76 Nat. b. 47: 'cum interrogarentur, cuius auctoritate scripturae ista facerent, hoc de Thesauro suo prodidisse, quod paulo ante commemoraui'.

77 Nat. b. 47: 'Unde manifestum est, quia hoc etiam si isti non faciunt, de ipsorum libris hoc faciunt quicumque faciunt. Abiiciant ergo libros, si crimen exhorrent, quod committere coguntur, si libros tenent'.
} 
Summary of Augustine's argument on the basis of Manichaean doctrine

Summarizing Augustine's reasoning on the basis of Manichaean doctrine, it may be articulated that

(a) the Manichaeans consider the vital substance (vitalis substantia, often termed the 'particles of light' or 'living soul'), which is dispersed in the life of plants, animals and human beings, as the very nature of God;

(b) whenever possible, this vital substance, i.e. God, should be released;

(c) according to Augustine, the doctrine logically ${ }^{78}$ and inevitably (note his digne, ${ }^{79}$ necessitas ${ }^{80}$ and coguntur $^{11}$ ) leads to the practice of 'human semen eucharist'.

Besides — as repeatedly stated by Hippo's bishop—-the books of Mani are the pernicious source of this horrible practice, and consequently the Manichaeans should completely reject these books. ${ }^{82}$

\section{Other Manichaean sources?}

After all, it may be clear that Augustine does not charge all Manichaeans with committing 'human semen eucharist'. In his opinion, it is only those identified in haer. 46 as the 'Catharists', who put the Seduction myth as described in Mani's Thesaurus into practice.

It seems to be for this reason that—apart from the relevant parts of Mani's cosmogonic myth - one does not find other Manichaean texts to underpin the described practice as being Manichaean. The Coptic Manichaean Psalmbook contains several episodes of Mani's cosmogony, but there are only minor reminiscenses of the myth of the archons' seduction ${ }^{83}$ and not the sligthest hint at any 'human semen eucharist'. The

\footnotetext{
78 One may also note Mani's speaking of causa, ratio and cogitaverunt in his 'Seduction' myth as related in the passage from book 7 of his Thesaurus quoted above.

79 Nat. b. 45 (see n. 72).

80 Nat. b. 46 (see n. 73)

81 Nat. b. 47 (see n. 76).

82 Nat. b. 45 ('... quod frustra negant, nisi eosdem libros anathemauerint'); 47 ('... de ipsorum libris hoc faciunt quicumque faciunt. Abiiciant ergo libros, si crimen exhorrent, quod committere coguntur, si libros tenent; aut si non committunt, mundius uiuere contra suos libros conantur'. Cf. e.g. haer. 46,10. ${ }^{83}$ Cf. Psalm 223 in C.R.C. Allberry (ed., transl.), A Manichaean Psalm-Book, Stuttgart 1938, 9-11. In the $7^{\text {th }}$ Psalm of Thomas (Psalm-Book, 213) it runs: 'he (the Living Spirit) planted him a plant in the lives, he called his beloved ones, he set them up upon it that they might purify the seed and take it forth ... and purify ... the seed and take it [forth upon the] ships and the barks', but I do not consider this to be an explicit reminiscence of the Seduction myth. Perhaps the most explicit reference is in Psalm 219 (Psalm-Book, 2): 'The beloved Daugther of her Father, the blessed maiden of Light (?), who puts to shame by her ineffable beauty the powers that are full ...'. I have confined my search to the (second and, until now, only edited) part of the Psalm-Book, i.e., without consulting S. Giversen's facsimile edition of the first part.
} 
same goes for several sections of the Coptic Kephalaia in which Mani's cosmogony is discussed: there are some reminiscences of the myth, ${ }^{84}$ but no hints at a eucharist in which human semen is consumed.

Other Manichaean sources preceding or contemporary to Augustine' time and world do not contain evident details either. Among the later sources one finds the Seduction myth discussed in, for instance, al-Bīrūnì's quote from Mani's Thesaurus ${ }^{85}$ and the excerpts from Mani's books ${ }^{86}$ handed down by Theodor bar Kōnai. ${ }^{87}$ None of these authors, however, hint at some 'human semen eucharist'. As far as I can see, the same goes for the Manichaean texts from Turfan, Tun-huang and related discoveries now being published in the Corpus Fontium Manichaeorum. 88

\section{The wider 'gnostic' context}

To the students of 'gnostic' texts, however, the whole matter as decribed above will not be so strange. One may even say: on the contrary. The Seduction myth was part and parcel of the world view of many a gnostic sect and combined with it was the idea of 'gathering in' (syllexis) of the dispersed particles of light.

An excellent example in this regard is the sect termed by Epiphanius as the 'Gnostics' or 'Borborites'. ${ }^{89}$ According to his report, these 'Gnostics' or 'Borborites' 90 believed there

${ }^{84}$ E.g. Kephalaion VI in Kephalaia (ed., transl. H.J. Polotsky), Band I, 1. Hälfte (Lieferung 1-10), Stuttgart 1940, 30-34. Here, too, I have confined my search to the - up till now-edited parts of the Kephalaia. A search of the Coptic Manichaean Homilies did not yield any evident parallels.

85 Cf. Adam, Texte, 5. Al-Bīrūnì's Arabic work Chronology of Ancient Nations is usually dated to c. 1000 CE. 86 Or book? According to Tardieu, Le manichéisme (n. 34), 56 these excerpts stem from Mani's Pragmateia. ${ }^{87}$ Cf. Adam, Texte, 19, 20, 21. Theodor bar Kōnai's Syriac source Liber scholiorum is dated to c. 790. 88 Cf. D. Durkin-Meisterernst (ed.), Dictionary of Manichaean Texts, Vol. III, 1: Texts from Central Asia and China (Texts in Middle Persian and Parthian), Turnhout 2004; F. de Blois, N. Sims-Williams, E.C.D. Hunter (eds.), Dictionary of Manichaean Texts, Vol. II: Texts from Iraq and Iran (Texts in Syriac, Arabic, Persian and Zoroastrian Middle Persian), Turnhout 2006; N. Sims-Williams, D. Durkin-Meisterernst, Dictionary of Manichaean Texts, Vol. III, 2: Texts from Central Asia and China (Texts in Sogdian and Bactrian), Turnhout 2012. As a matter of fact, some texts have reminiscences of Mani's pivotal Seduction myth; see e.g. F.C. Andreas \& W.B. Henning, Mitteliranische Manichaica aus Chinesisch-Turkestan, Berlin 1932, 194 and, for the (androgynous) Virgins of Ligth e.g. Tsui Chi, 'Mo Ni Chiao Hsia Pu Tsan, The Lower (Second?) Section of the Manichæan Hymns', BSOAS 11 (1943-1946) 179.

${ }^{89}$ Epiphanius, Panarion, 26. In actual fact Epiphanius (Pan. 21,2,5) already credited the 'Simonians' with some sort of Seduction myth connected with the figure of Prounikos ('she is called Barbero or Barbelo by other sects'). The same goes for the 'Nicolaitans' from whom, according to him, these 'Gnostics' or 'Borborites' (they are also termed with several other names, cf. e.g. Pan. 25,2,1 and, in particular Anakephalaiosis 2,26,1-2: 'In Egypt they are called Stratiotics and Phibionites; in Upper Egypt, Secundians; in other places, Socratists, and Zachaeans in others. But others call them Coddians, others, Borborites') directly sprang.

${ }^{90} \mathrm{I}$ adopt the names mentioned in the subscription of $\int 26:$ 'Against the Gnostics or Borborites, Number six, but twenty-six of the series'. Here and elsewhere I quote the translation of Frank Williams, 
was a primordial Spirit who brought forth Barbelo. This Barbelo (or Prounikos) brought forth Ialdabaoth (or Sabaoth), who is the creator of the lower world. ${ }^{91}$ Not only the archons of the lower world, but all things created and living have a spark of Barbelo's power (dynamis). But Ialdabaoth boasted himself to be 'the first and the last, and there is none other God beside me' (cf. Isa 44:6; 45,5). ${ }^{92}$ Having heard this, Barbelo realized that the creation of the lower world was an error. She set out to recuperate as much of her power (dynamis) as she could: 'And she keeps appearing in some beautiful form to the archons and stealing the seed which is generated by their climax and ejaculationsupposedly to recover her power (dynamis) which has been sown in various of them'. ${ }^{93}$

According to these 'Gnostics', salvation consists in the collection and restoration of Barbelo's lost power (dynamis). Already with regard to the Nicolaitans (or their followers ${ }^{94}$ Epiphanius communicates: '... they say in mythological language ... of their disgusting behavior, "We are gathering the power (dynamis) of Prunicus from our bodies, and through their emissions." That is, <they suppose they are gathering $>$ the power (dynamis) of semen and menses'. ${ }^{95}$ Speaking of the 'Gnostics' or 'Borborites', he tells that they celebrate their promiscuous Agape feast:

'For after having made love with the passion of fornication in addition, to lift their blasphemy up to heaven, the women and man receive the man's emission on their own hands. And they stand with their eyes raised heavenward but the filth on their hands and pray, if you please- the ones they call Stratiotics and Gnostics — and offer that stuff on their hands to the true Father of all, and say: "We offer thee this gift, the body of Christ". And then they eat it partaking of their own dirt, and say: "This is the body of Christ: and this is the Pascha, because of which our bodies suffer and are compelled to acknowledge the passion of Christ". And so with the women's emission when she happens to be having her period - they likewise take the unclean menstrual blood they gather from her, and eat it in common. And "This", they say, "is the blood of Christ"". 96

Quite evidently, Epiphanius describes some 'human semen eucharist'. Perhaps even more important in our context is that he also gives some insight into the reasoning of his 'Gnostics': 'They say that the flesh must perish and cannot be raised, and this belongs to the archon. But the power (dynamis) in the menses and organs is soul (psyche), they say, "which we gather and eat. And whatsoever we eat-meat, vegetables, bread or anything else-we are doing creatures a favor by gathering the soul (psyche) from them all and

The Panarion of Epiphanius of Salamis. Book I (Sects 1-46). Second Edition, Revised and Expanded, Leiden-

Boston 2009.

${ }^{91}$ Cf. Pan. 25,2,1.

92 Pan. 25,2,3.

93 Pan. 25,2,4.

${ }^{94}$ From the text it is not completely clear whether Epiphanius is still speaking of the Nicolaitans proper or (more probably) already has their followers in view.

95 Pan. 25,3,2.

96 Pan. 26,4,5-8. 
taking it to the heavens with us"' ${ }^{97}$ Frank Williams, in his just quoted translation, for the idea of 'gathering the soul' rightly refers in some footnotes to parallels in Manichaean texts. ${ }^{98}$ Others have referred to other texts, even undisputed 'orthodox' Christian and Mandaean texts. ${ }^{99}$

\section{Conclusion}

From the above, one thing may have become clear: we should try to understand both Manichaeans (like the 'Catharists') and Gnostics (like the 'Borborites') according to their own logic. Both appear to have considered the life-substance of man, the semen, as divine, indeed a part of God. The seed of light, in the form of the male semen and the female menstrual blood, should not be allowed to escape, but should get back to God. Although, in all likelihood, we will do wise not to take all details of Epiphanius' descriptions seriously, ${ }^{100}$ the fact of 'human semen eucharist' among some Gnostics seems to be corroborated by the fierce polemic against it in other Gnostic texts. ${ }^{101}$

As far as I can see, in the case of the Manichaeans we do not have texts which point to a similar inner-Manichaean discussion. What we do know, however, is that the Manichaean movement was more variegated than usually assumed. ${ }^{102}$ Indeed, 'Catharists' seem to have been a variant among the Manichaeans, considered by others to be deviant. Up to now, the only text testifying to this appears to be Augustine's haer. 46,10.

${ }^{97}$ Pan. 26,9,3-4.

${ }^{98}$ Williams, Panarion (n. 90), 97 n. 43 with reference to Keph. 191,16-17; 212,10-22; 236,7-27. Cf. Williams, ibidem, 92 n. 17 referring to Keph. 228,1-2 and Psalm-Book 175,19. And see already K. Rudolph, Gnosis. The Nature and History of Gnosticsm. Translation edited by R. McL. Wilson, San Francisco 1987, 250: 'This [sc. the full quote Epiph. Pan. 26,9,4] is reminiscent of the Manichaean feasts of the "elect", which serve the "gathering of the souls".

${ }^{99}$ S. Benko, 'The Libertine Gnostic Sect of the Phibionites according to Epiphanius', VC 21 (1967) 103-119 who (118-119) even sees 1 Joh 3:9 and Did. 9,4 as parallels. For possible Mandaean parallels, cf. J.J. Buckley, 'Libertines or Not: Fruit, Bread, Semen and Other Body Fluids in Gnosticism', JECS 2 (1997) 24-28.

100 E.g. his example of the 'myth of ritual murder' in Pan. 26,5,5; cf. e.g. Rudolph, Gnosis, 249.

101 See e.g. Pistis Sophia 4, 147 (cf. Pistis Sophia. Text established by Carl Schmidt. Translation and Notes by Violet MacDermot, Leiden etc. 1978, 381) and 2 Jeu 43 (cf. C. Schmidt [ed.], The Books of Jeu and the Untitled Text in the Bruce Codex. Translation and Notes by V. MacDermot, Leiden etc. 1978, 100). Cf. e.g. Rudolph, Gnosis, 250 and Williams, Panarion, 94.

102 Apart of the 'Catharists', in A.'s time and world there were the 'Mattarii' (c. Faust. 5,5; haer. 46,10); from later sources we know of several other schisms. See further R. Lim, 'Unity and Diversity Among Western Manichaeans: A Reconsideration of Mani’s sancta ecclesia’, REA 35 (1989) 231-250. 